\title{
日㷌り人間ドックに抢ける耐糖能異常者の スクリーニング法の検討
}

平野久美子 ${ }^{1)}$ 嗣辺 かほる 二 橋 めぐみ 鈴木 昌子 山田万利子 清 見定 道 ${ }^{2}$ 山澤 宏

\section{緒 言}

日帰り人間ドックにおける耐糖能異常者のスク リーニング (以下 Sc と略す) 検査は時間的制約や 他の検査への影響等を考慮すると, 糖尿病学会勧 告1)に従って忠実に検査を組み入れることは困難 である。しかし，その限定された条件の中でプロ グラムに支障を来すことなく効率良く目的を達成 させることは重要な課題である。

当診療所ではこれまで簡便法として空腹時血糖 值 (以下 FPG と略す) と昼食後一時間の血糖值を 参考にして一次 Sc を実施して来ており, 筆者等 はこの方法の妥当性についての検討結果を 1985 年の人間ドック学会において発表した ${ }^{2)}$ 。

近年, グリコヘモグロビン (以下 $\mathrm{HbA}_{1 \mathrm{c}}$ と略す) の測定が導入され, 糖尿病のコントロールの指標 3 6) として日常診療の中で重要視されるようにな り, Sc としての有用性についても評価されて来て いる ${ }^{7,8)}$ 。

また, 最近ではフルクトサミン (以下 FRA と略 す) の臨床的意義が話題となり, $\mathrm{HbA}_{\mathrm{lc}}$ と同様糖

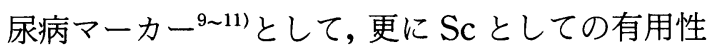
${ }^{12), 13)}$ についても検討されている。

本研究では FPG と FRA（以下 I 群と略す）並 びに FPG と $\mathrm{HbA}_{1 \mathrm{c}}$ (以下II群と略す) との組合せ について基準值, Sc 効果を 75 gGTT の成績と対 比して検討を行なった。

\section{Glucose Tolerance Screening Method In Human} Dry Dock

1) 芙蓉診療所

2）東京医科大学第二内科

(1989 年 7 月 13 日受稿)
尚, 合わせて二つの検査センターにおける測定 值についての比較検討を行なった。

\section{対象並びに方法}

1. 短期人間ドック受診者 208 名, 糖尿病を疑 われて来院した外来患者 4 名, 計 212 名を対象と した。全例に $75 \mathrm{gGTT}$ を実施し, 同時に FRA と $\mathrm{HbA}_{1 \mathrm{c}}$ とを測定した。各検查值の測定は以下の方 法によった。

1）血糖はグルコースオキシダーゼ法

2) FRA は Johnson 等の方法 ${ }^{9), 10)}$ に準じた比 色 (NBT) 法

3) $\mathrm{HbA}_{1 \mathrm{c}}$ は高速液体クロマトグラフ (HPLC) 法 ${ }^{14), 15)}$ で測定した。

尚, 血糖検查は当施設内で実施し, FRA 及び $\mathrm{HbA}_{1 \mathrm{c}}$ は他の検査センターに依頼した。

基準值に関しては, FRG は $110 \mathrm{mg} / \mathrm{dl}$ とし, FRA 及び $\mathrm{HbA}_{1 \mathrm{c}}$ については以下の如くにした。 即ち, 対象者の $75 \mathrm{gGTT}$ の結果を学会勧告に基 づいて型分類し, その正常型の平均值 $(\bar{x})$ と標準 偏差 $(\mathrm{SD})$ を算出し，その $\overline{\mathrm{x}}+1 \mathrm{SD}$ または $\overline{\mathrm{x}}+2$ $\mathrm{SD}$ を仮の基準値と設定し, I 群及びII群におけ る基準值, $\mathrm{Sc}$ 率, $\mathrm{Sc}$ 効果の比較検討を行なった。

2. 当診療所が依頼した検査センターの FRA 及び $\mathrm{HbA}_{1 \mathrm{c}}$ 測定值が共に, 文献や他の施設の数值 8),12),13),16)に比較して低值を示したため，更に別の 検査センター一社を選び，新たに人間ドック受診 者 272 名の FRA 及び $\mathrm{HbA}_{1 \mathrm{c}}$ 值を測定し, 検査セ ンター間の比較と, 更にその測定值についても今 回の対象との間で比較検討を行なった。

\section{成 績}

1. 対象 212 例の $75 \mathrm{gGTT}$ 成績を糖尿病学会 


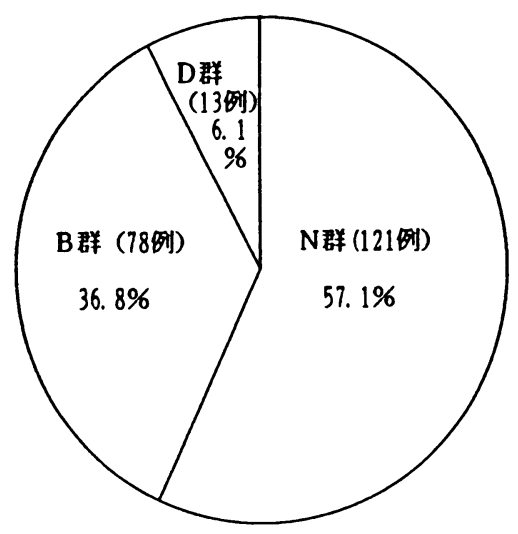

図 175 gOGTT 成績の型別頻度
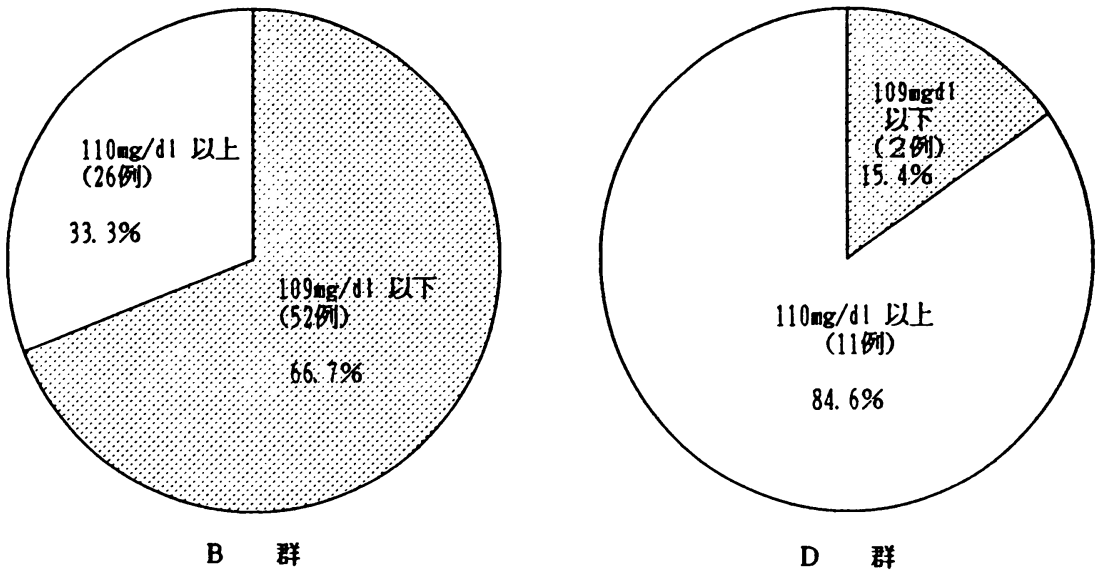

図 2 B 群・D 群における FPG 正常者・異常者の占める割合

勧告に基づいて分類すると,図 1 の如く正常型(以 下N群と略す）121例（57\%）境界型（以下B群 と略す） 78 例 (37\%), 糖尿病型（以下 D群と略 す) 13 例 (6\%)である。B群及びD群のうち FPG 值が正常 $(109 \mathrm{mg} / \mathrm{dl}$ 以下) を示す例の占める割合 は図 2 の如くB群 78 例中 52 例 $(67 \%), \mathrm{D}$ 群 13 例中 2 例 $(15 \%)$ である。

各群における FRA ならびに $\mathrm{HbA}_{1 \mathrm{c}}$ の測定值 $(\overline{\mathrm{x}}+\mathrm{SD})$ を表 1 に示す。FRA 值 $(\mathrm{mmol} / \mathrm{l})$ は $\mathrm{N}$ 群 $2.32 \pm 0.17$, B 群 $2.41 \pm 0.19$, D群 $3.04 \pm 0.73$ であり, 一方 $\mathrm{HbA}_{1 \mathrm{c}}(\%)$ 值は $\mathrm{N}$ 群 $4.63 \pm 0.32$,

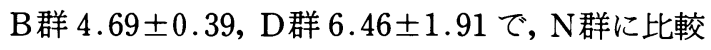
して, FRA 及び $\mathrm{HbA}_{\mathrm{lc}}$ 共に, $\mathrm{B}$ 群・ D群は有意 $(\mathrm{P}$
<0.05)に高値を示している。

尚, $\overline{\mathrm{x}}$ と $\mathrm{SD}$ から求めた FRA 及び $\mathrm{HbA}_{\mathrm{ic}}$ の変 動域 $(\mathrm{CV})$ はそれぞれN群 $7.0 \%, 5.9 \%, \mathrm{~B}$ 群 $8.0 \%, 8.4 \% ， \mathrm{D}$ 群 $24.3 \% ， 30.0 \%$ であ。

各検查項目間の相関関係を図 3 に示す。FPG と FRA との間には相関係数 $r=0.771, F P G$ と $\mathrm{HbA}_{\mathrm{lc}}$ との間には $r=0.833$ と有意な正の相関を 認める。また図 4 に示す如く 75 gGTT 3 時点の 血糖值の総和 (以下 $\Sigma \mathrm{GTT}$ と略す) と FRA との 間には $r=0.733, \Sigma G T T$ と $\mathrm{HbA}_{1 \mathrm{c}}$ との間には $r$ $=0.800$ と有意な正の相関を認め, 更に, 図 5 の如 く FRA と $\mathrm{HbA}_{1 \mathrm{c}}$ との間には $r=0.785$ と全ての 項目間において有意 $(\mathrm{p}<0.05)$ の正の相関が認め 
表 175 gOGTT 判定分類別, 項目別の平均値, 標準偏差並びに変動係数比較表

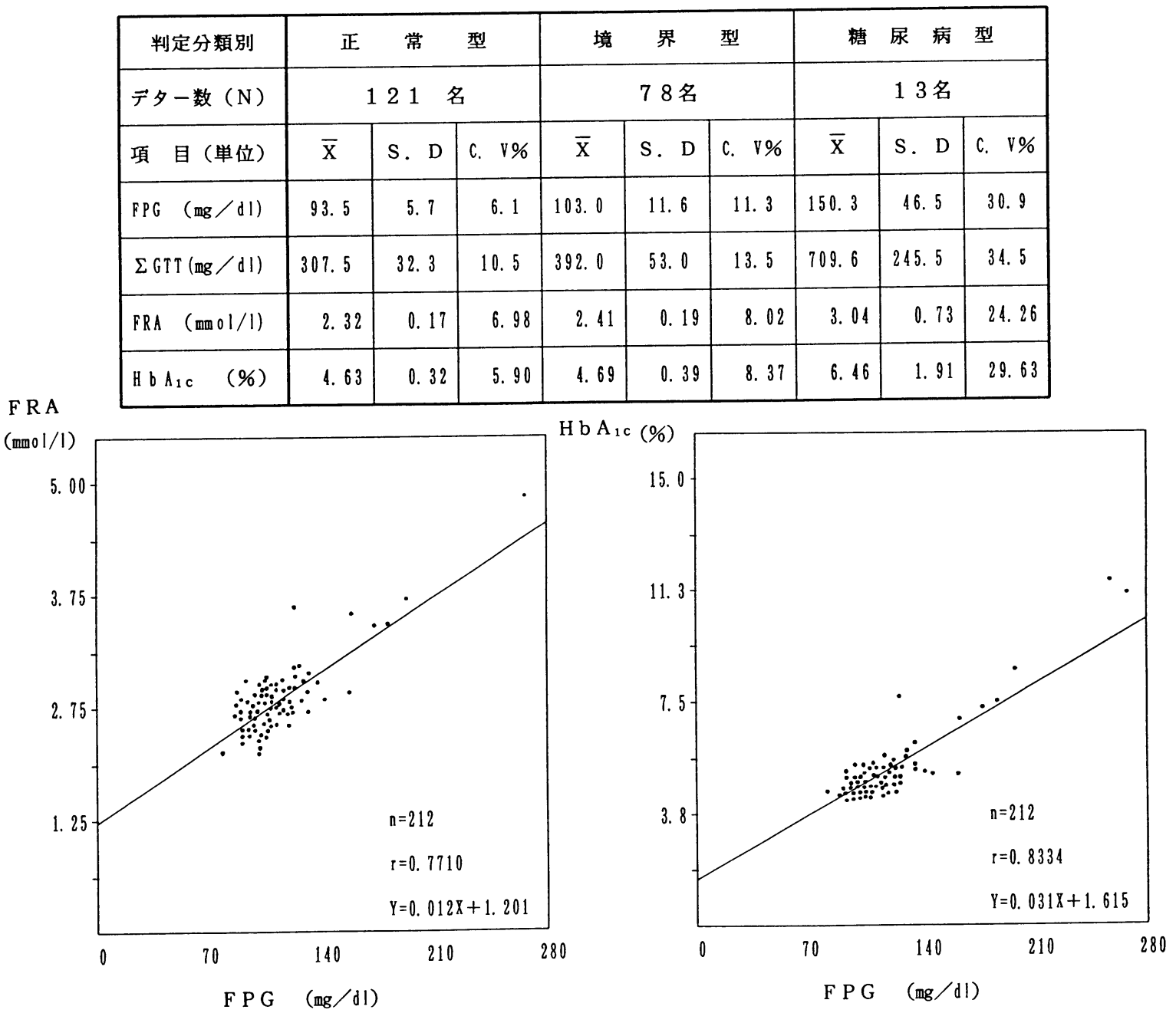

図 3 FPG と FRA, $\mathrm{HbA}_{1 \mathrm{c}}$ との関係

表 2 I 群（FPG \& FRA の組合せ）FRA の基準值の差異によるスクリーニングの比較

\begin{tabular}{|c|c|c|c|c|}
\hline 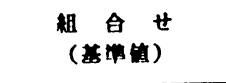 & $\begin{array}{c}\text { F P G \& } \\
\left(110_{\mathrm{m} / \mathrm{B}} / \mathrm{dI}\right)\end{array}$ & $\begin{array}{l}\text { F R A } \\
(\bar{x}+2 S D)\end{array}$ & $\begin{array}{c}\text { FPG \& } \\
(111 \mathrm{mg} / d \|)\end{array}$ & $\begin{array}{l}F R \wedge \\
(\bar{x}+(S D)\end{array}$ \\
\hline 判 & $\mathrm{sc}$. & $n-S c$. & Sc. & A-S c. \\
\hline$N \quad(n=121)$ & 8 & 113 & 18 & 103 \\
\hline B $\quad(n=18)$ & 23 & 55 & 36 & 42 \\
\hline D $\quad(n=13)$ & 11 & 2 & 12 & 1 \\
\hline A It $\quad(n=212)$ & 42 & 170 & 66 & 146 \\
\hline 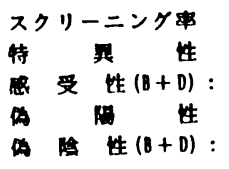 & $\begin{array}{rl}2 & 0 \\
9 & 3 \\
3 & 7 \\
\quad 7 \\
63\end{array}$ & $\begin{array}{l}96 \\
96 \\
96 \\
96 \\
96\end{array}$ & $\begin{array}{ll}3 & 1 \\
8 & 5 \\
5 & 3 \\
1 & 5 \\
4 & 7\end{array}$ & $\begin{array}{l}96 \\
\% \\
\% \\
\% \\
\%\end{array}$ \\
\hline
\end{tabular}


F R A

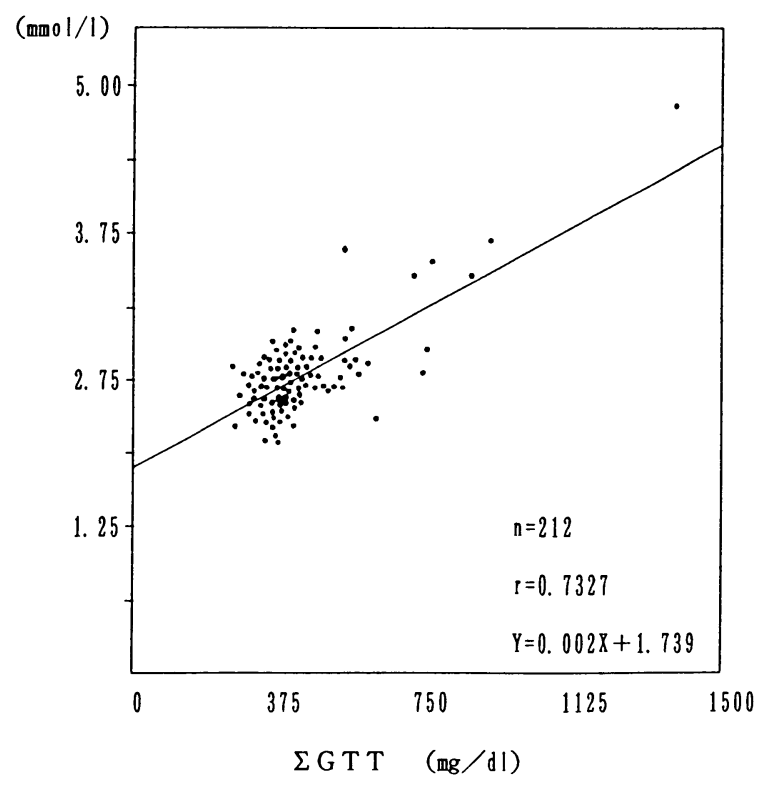

$\mathrm{H}$ b $\mathrm{A}_{1 \mathrm{c}}$

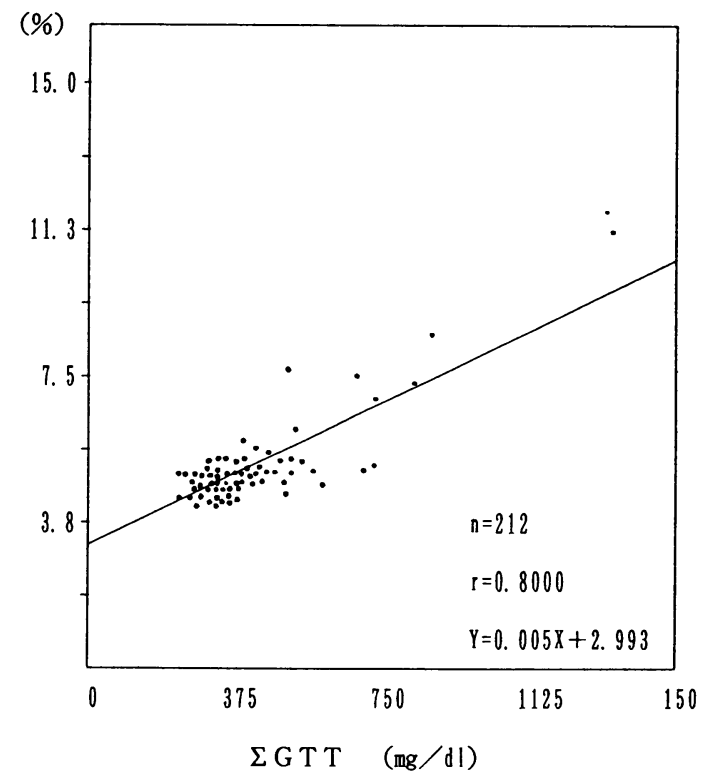

図 475 gOGTT 3 時点血糖値の総和 $(\Sigma \mathrm{GTT})$ と FRA, $\mathrm{HbA}_{1 \mathrm{c}}$ との関係

図 5 FRA と $\mathrm{HbA}_{1 \mathrm{c}}$ の関係

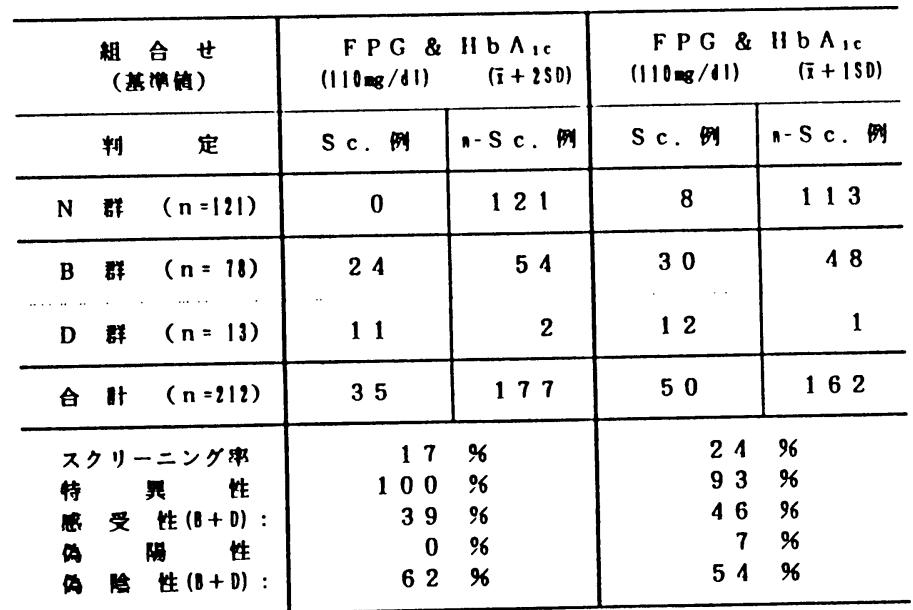

表 3 II 群 (FPG \& $\mathrm{HbA}_{1 \mathrm{c}}$ の組合せ) における $\mathrm{HbA}_{1 \mathrm{c}}$ の基準値の差 異によるスクリーニングの比較

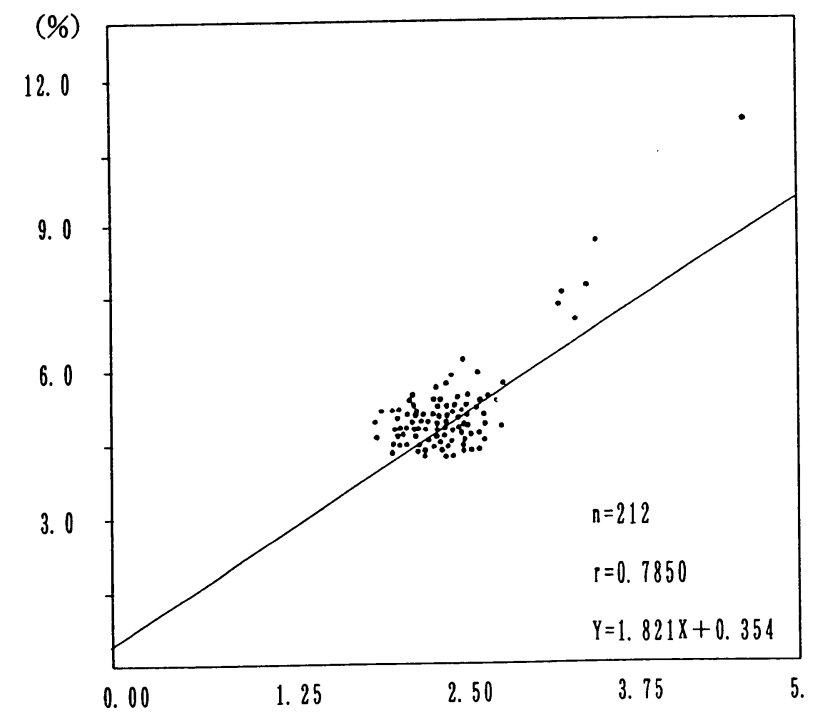

FRA (mg/dI) 

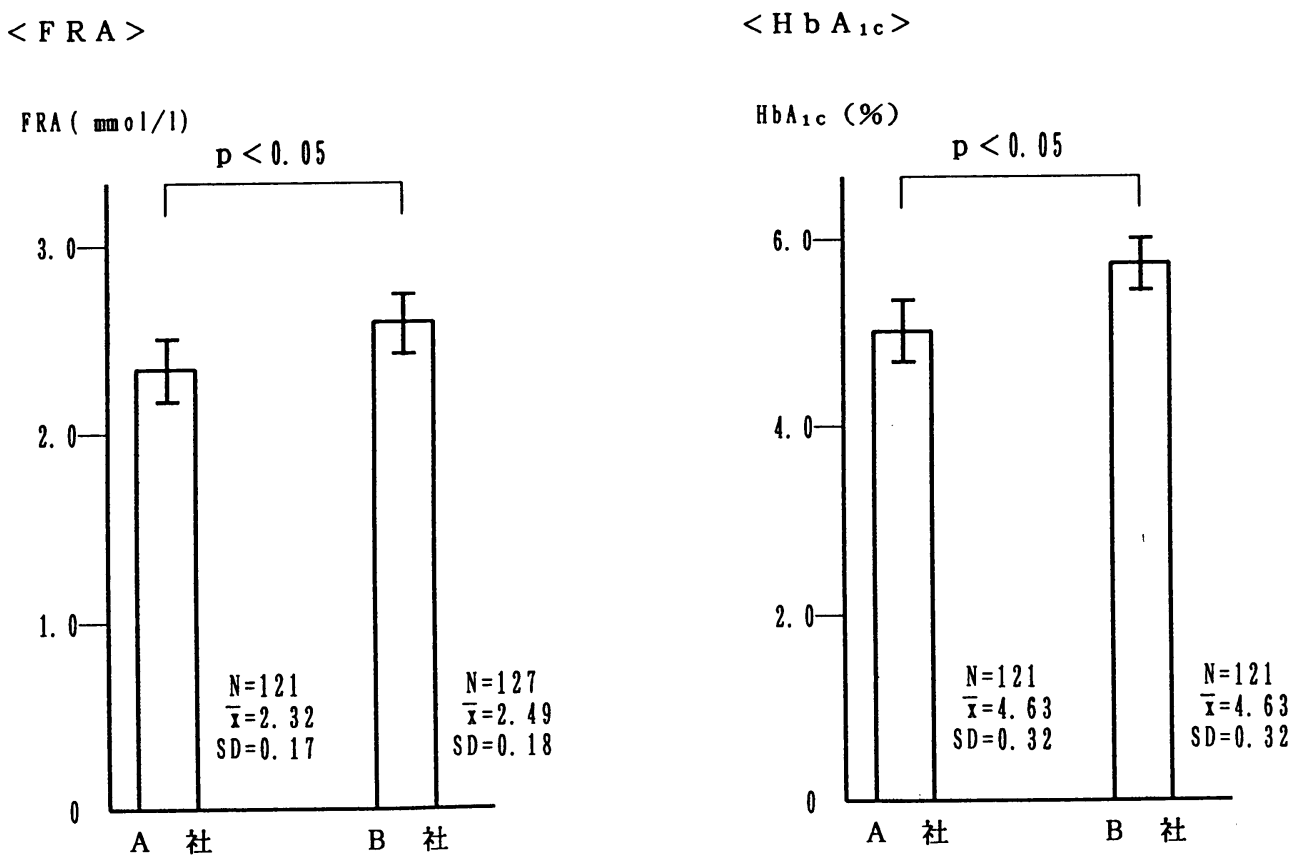

図 62 検査センター間における $\mathrm{HbA}_{1 \mathrm{c}}$ 並びに FRA 值の比較

られる。

今回求めた FRA 及び $\mathrm{HbA}_{1 \mathrm{c}}$ の測定值の $\overline{\mathrm{x}}$ と $\mathrm{SD}$ を用いて，その $\overline{\mathrm{x}}+1 \mathrm{SD}$ または $\overline{\mathrm{x}}+2 \mathrm{SD}$ の近 似値を基準值と仮に設定した。FRA 及び $\mathrm{HbA}_{1 \mathrm{c}}$ 值の各々と FPG 值 $110 \mathrm{mg} / \mathrm{dl}$ とを組合せて少な くとも一方が基準値以上を示す場合を陽性とし， $\mathrm{Sc}$ を行なった。I 群における FRA の基準値の差 異による Sc 成績と Sc 効果の比較を表 2 に示す。 即ち，FRAの基準值を $\overline{\mathrm{x}}+2 \mathrm{SD}$ または $\overline{\mathrm{x}}+1 \mathrm{SD}$ とした時, Sc 率は各々 $20 \%, 31 \%$, 特異性 $93 \%$, $85 \%$ ，感度はそれぞれ $37 \% ， 53 \%$ である。また， 偽陽性は各々 $7 \% ， 15 \%$ であり，偽陰性は $63 \%$, 47 \%である。

次に, II群における $\mathrm{HbA}_{1 \mathrm{c}}$ の基準値の差異によ る $\mathrm{Sc}$ 成績と $\mathrm{Sc}$ 効果の比較を表 3 に示す。即ち, $\mathrm{HbA}_{1 \mathrm{c}}$ の基準值を $\overline{\mathrm{x}}+2 \mathrm{SD}$ または $\overline{\mathrm{x}}+1 \mathrm{SD}$ とし た時, Sc 率は各々 $17 \%$ ，24\%，特異性 $100 \%, 93$

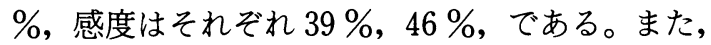
偽陽性は各々 $0 \% ， 7 \%$ であり，偽陰性は $62 \%$, $54 \%$ あ゙ある

2. 今回の測定を依頼した検査センター（A
社）での FRA 及び $\mathrm{HbA}_{1 \mathrm{c}}$ の測定值が低值であっ たため，他の一社（B社）を選び比較した。

$\mathrm{B}$ 社における検查の対象者は 272 例である。そ のうち 75 gGTT の結果, 正常型を呈した例は 127 例 $(47 \%$ )であり，N群の測定值 $\overline{\mathrm{x}} \pm 1 \mathrm{SD}$ は FRA が $2.67 \mathrm{mmol} / \mathrm{l}, \mathrm{HbA}_{1 \mathrm{c}}$ が $6.0 \%$ であった。これ に比して $\mathrm{A}$ 社の測定值 $(\overline{\mathrm{x}}+1 \mathrm{SD})$ は FRA が $2.49 \mathrm{mmol} / 1, \mathrm{HbA}_{1 \mathrm{c}}$ が $5.0 \%$ であった。以上の如 く $\mathrm{B}$ 社の測定值は FRA 及び $\mathrm{HbA}_{1 \mathrm{c}}$ 共に高值を 示し, $A \cdot B$ 社間に有意差 $(P<0.05)$ が認められた (図 6 )。

\section{考 察}

FRA 及び $\mathrm{HbA}_{1 \mathrm{c}}$ に関し，糖尿病のコントロー ルの指標としての有用性については既に広く知ら れている 3 6,9 11)。しかし, FRA または $\mathrm{HbA}_{1 \mathrm{c}}$ 単独 あるいはこれらと FPG との組合せによる Scの 指標としての有用性については種々報告がなされ てはいるものの ${ }^{7,8,12,13)}$ その多くが治療医学を主体 としたもので, 予防医学の見地から統一された基 準がないのが現況である。 
本研究では，日帰り人間ドックにおける耐糖能 異常者の Sc として, FPG と FRA 及び FPG と $\mathrm{HbA}_{1 \mathrm{c}}$ とを組合せて $75 \mathrm{gGTT}$ と対比し，その判 定基準及び $\mathrm{Sc}$ 効果等について検討した。同時に 検査センター間の FRA 及び $\mathrm{HbA}_{1 \mathrm{c}}$ の測定值並 びに基準値についての検討を行なった。

1. FRA 及び $\mathrm{HbA}_{1 \mathrm{c}}$ の測定值は, D群は B 群 N群に比して有意に高値を示した。FPG, $\Sigma G T T$, FRA 及び $\mathrm{HbA}_{1 \mathrm{c}}$ の各項目間には有意な正の相関 関係が認められ，その係数間には差が認められな かった。

時間的制約やその他の問題があるとは言え FPG 単独成績で Sc した場合 D 群の $15 \%$ ，B群 の $69 \%$ \%見逃しとなる。そこでその危険性を少な くするため FPG と FRA あるいは $\mathrm{HbA}_{1 \mathrm{c}}$ とを組 合せて $75 \mathrm{gGTT}$ の成績と対比して検討した。基 準值については, FRA 及び $\mathrm{HbA}_{1 \mathrm{c}}$ を $\overline{\mathrm{x}}+2 \mathrm{SD}$ ま たは $\overline{\mathrm{x}}+1 \mathrm{SD}$ とした時の $\mathrm{Sc}$ 効果は, $\overline{\mathrm{x}}+2 \mathrm{SD}$ に 比し $\overline{\mathrm{x}}+1 \mathrm{SD}$ では両群ともに Sc 率, 感受性, 偽陽 性は高值を示し, 一方特異性, 偽陰性は低值を示 した。

予防医学の見地から糖尿病型は勿論のこと境界 型域までの耐糖能異常者の検出に努めるならば, 以上の成績から Sc 率, 偽陽性が多少多くなった としても, 一次 Sc の方向としては感受性が高く, 偽陰性の少ない $\overline{\mathrm{x}}+1 \mathrm{SD}$ を基準值と設定するこ とにより，より $\mathrm{Sc}$ 効果が期待できることを示し ている。しかし, この点については, さらに検討 を続ける予定である。

そこで，FRA 及び $\mathrm{HbA}_{1 \mathrm{c}}$ の基準值を $\overline{\mathrm{x}}+1 \mathrm{SD}$ と設定した時の， I 群と II 群における Sc 効度を 比較して見ると, Sc 率は I 群 $31 \%$, II群では 24 \%で I 群がやや高值を示し, 特異性は各々 $85 \%$, $93 \%$ で多少の差は認められるが両群共に極めて 良く, より広範囲に耐糖能異常者を検出するため B 群を含めて扱ったため, 感受性は, 各々 $53 \%$, $46 \%$ とやや低い成績となっている。しかし, 両群 間に大差は認められなかった。また, 偽陽性は I 群では $15 \%$, II群では $7 \%$ で, 両群とも少なく, 一方, 偽陰性は B 群の存在のため各々 $47 \%, 54 \%$ とやや多く認められているものの, 以上の成績よ り両群間に大差はなく, 共に耐糖能異常者の Sc
としての有用性が示唆された。

2. 検查センター間の測定值を比較した結果有 意差が認められ, 当診療所で利用している $\mathrm{A}$ 社の 測定値が低值であることが今回の検討で明らかに なった。A 社設定の基準值(上限)は FRA が 2.80 $\mathrm{mmol} / 1, \mathrm{HbA}_{1 \mathrm{c}}$ が $6.0 \%$ あ゙あのに対して今回 の我々の成績では, $\bar{x}+1 \mathrm{SD}$ で FRA $2.5 \mathrm{mmol} /$ $1, \mathrm{HbA}_{1 \mathrm{c}} 5.0 \%$ であり, $\overline{\mathrm{x}}+2 \mathrm{SD}$ としても FRA が $2.66 \mathrm{mmol} / \mathrm{l}, \mathrm{HbA}_{1 \mathrm{c}}$ が $5.3 \%$ で, A社で測定 したにも拘らず特に $\mathrm{HbA}_{1 \mathrm{c}}$ においては $\mathrm{A}$ 社での 設定值より低い值となった。

以上の結果，検査センターを利用する施設にお いて新しい検査を導入する場合，その検査におけ る基準值について検討する必要性が示唆された。

\section{結 語}

1. FPG, $\Sigma$ GTT, FRF, $\mathrm{HbA}_{1 \mathrm{c}}$ の全ての項目 間において高い相関関係を認めた。

2. FRA 及び $\mathrm{HbA}_{1 \mathrm{c}}$ 值は $\mathrm{D}$ 群, $\mathrm{B}$ 群, $\mathrm{N}$ 群の順 に高值を示し, 各群の間には有意差が認められた。 $\mathrm{D}$ 群は B 群 $\mathrm{N}$ 群に比べ, 鋭敏にスクリーニングさ れた。

3. FPG及びFRA あるいは FPGと $\mathrm{HbA}_{1 \mathrm{c}}$ との組合せのいずれも糖尿病スクリーニングとし て有用であることが示唆された。

4. 予防医学の見地から, 糖尿病型は勿論のこ と，境界型域までの検出に努めるならば，若干の 正常者を含む危険性を考慮しても，FRA または $\mathrm{HbA}_{1 \mathrm{c}}$ の基準值は $\overline{\mathrm{x}}+1 \mathrm{SD}$ とすることが望まし いと考えられる。更に検討が必要である。

5. FRA は $\mathrm{HbA}_{1 \mathrm{c}}$ と比較して, (1)禟尿病, 境界 型糖尿病の検出率については有意差がない。(2)検 体が他の生化学検査と共用可能。(3)検体保存が容 易。(4)低コストなどの利点があり, 日帰り人間ド ックにおける耐糖能異常者のスクリーニングとし ては, FPG と FRA の組合せがより有用性が高い と考えられるが更に検討を重ねていく予定であ る。

6. 検査センターを利用する場合，基準値の検 討が必要であることが明らかとなった。

(本論文の要旨は第 29 回人間ドック学会において, 発 表した。) 


\section{謝 辞}

本研究に際して多大のご配慮を戴いた成人病医 学センター理事長, 資料の統計処理などでご助力 下さった芙蓉診療所検査科の方々に謝意を表しま す。

\section{文 献}

1） 小坂樹徳, 他：糖尿病の診断に関する委員会報 告, 糖尿病, $25: 859-860,1982$.

2）平野久美子, 堺 真紀, 渡辺満利子, 立石誌司, 清 見定道, 山澤 宏: 日帰り人間ドックにおける 耐糖能異常者のスクリーニングについて, 日健 診誌, 15 (1) : 17-20, 1988.

3）稲田道夫：糖尿病のコントロールの指標として Hemoglobin $\mathrm{A}_{1 \mathrm{c}}$ の意義, 糖尿病, 21 (1)：4649, 1978.

4）平田幸正：グリコへモグロビン，SRL＼cjkstart宝函， $4(2)$ : 15-18, 1980.

5）老粐宗忠: Hemoglobin $A_{1 c}$ 糖代謝異常, 臨床 病理, X X VII : 12, 1070-1074, 1979.

6）山東博之：へモグロビン $A_{1}, A_{1 c}$ の測定治療上 の意義, 診断と治療, 73 (8) : 1778-1781, 1985.

7）池田義雄, 坂本要一, 井出幸子, 南 信明, 斉藤 茂, 成宮 学: 糖尿病のスクリーニング検査と しての $\mathrm{HbA}_{1 \mathrm{c}}$ 測定の意義一定期健康診断 1762 名の成績から一, 日本医事新報, No. 2942： 1982.

8）清瀬闊, 田中剛二：へモグロビン $\mathrm{A}_{1 \mathrm{c}}$ と空腹 時血漿糖値 (FPG)の組み合わせによる耐糖能 スクリーニング法一日本総合健診医学会糖負荷
試験検討小委員会勧告案要約一，糖尿病， 30 (4) : 325-331, 1987.

9) Johnson RN, Metcalf PA, Beker JR: Fuructosamine : a new approach to the estimation of serum glycosylprotein Anindex of diabetic control. Clin. Chim. Acta 127 : 87-95, 1982.

10）倉八博之, 他：糖尿病における血清フルクトサ ミン值の臨床的意義, 糖尿病, 30 (11) : 987-994, 1987.

11) Beker JR, JohnsonRN, Scott DJ : Serum frukutosamine consentraion in patients with type II (non-in sulin-indep-endent) diabetes me llitus during changes in manegem ent. Brit, Med. J. 288 : 1484-1486, 1984.

12）石井周一, 飯村康夫, 櫻林郁之助, 河合忠: 糖尿 病のスクリーニングの指標としてのフルクトサ ミン測定の意義, 糖尿病, 31 (3) : 217-222, 1988.

13）江頭静摩, 江口和夫, 山崎晴一郎：フルクオサミ ン (FRA) の臨床とその応用 (FRA と FPG に よる糖尿病スクリーニング基準）, 臨床病理, $\mathrm{X}$ X VII : 148, 1988.

14) Gabbay, K. H., et al. : Glycosylated hemoglobins and long-term blood glucose control in diabetes mell itus., J.C.E. M., 44 : 859-864, 1977.

15）丸山昭治, 日吉末広： $\mathrm{HbA}_{\mathrm{lc}}$ の自動分析-Automatic Determination of Hemoglobin $A_{11}$, 日本 臨床検查自動化学会会誌, 12 (2) : 71-75, 1987.

16）河原玲子：へモグロビン $\mathrm{A}_{1 \mathrm{c}}$ （グリコへモグロ ビヅ $\left.\mathrm{A}_{1 c}\right)$, 日本臨床, 43：126-128, 1985. 